\section{British universities}

\section{Grants body answered}

THE Royal Society has strongly criticized the way the UK Department of Education and Science (DES) is planning its expenditure on higher education. In a published response to a questionnaire on its views on the future of higher education, the society says it is "disturbed" that spending plans seem to be based on an uncorroborated student demand projection that is lower than is likely to be the case.

A wide-ranging series of questions on the future of higher education in Britain was circulated last November by Sir Peter Swinnerton-Dyer, the chairman of the University Grants Committee (UGC) after a request from the Secretary of State for Education and Science for a full debate on how higher education should develop. The questions were criticized in many quarters for appearing to assume that a substantial reduction in the level of expenditure per student is in prospect.

Of the several published estimates of demand for university places to the end of the century, the Royal Society's are the lowest. They show demand as roughly constant from now until the end of the decade, falling by 18 per cent to $1995-96$ and rising thereafter. These estimates do not take account of the growing female participation rate, which is likely to increase demand for higher education. But the estimates of maximum total student demand promulgated by DES are below those thought plausible by the society, and DES appears now to be budgeting on its minimum demand projections.

Sir Peter Swinnerton-Dyer will not therefore be greatly surprised to learn that many of those replying have baulked at being asked to consider what would be the consequences of a 1 or 2 per cent reduction in the level of financial support per student. The University of Technology at Loughborough probably speaks for many when it says in reply to this question that "there is a natural tendency to shrink from answering.... on the assumption that any institution which thinks it could survive even the 1 per cent per annum reduction could well be asked to prove it",

Another contentious issue raised by the questionnaire concerns the earmarking of funds for research. At present, most of the universities' recurrent grant, paid by UGC, is for them to dispose of as they wish. But it has become an open secret in recent years that the cuts in real terms to UGC grants have compromised the universities' research capabilities, and the Medical Research Council has even gone so far as to make special provisions for universitybased research groups that were being adversely affected by UGC cuts. It has therefore been suggested that UGC might specify what proportion of universities' grant is to go to research, even to the level of earmarking allocations to individual projects.

\section{research projects.}

The Royal Society is ambivalent on this question. It proposes that the existing equipment grant, a component of recurrent grant already largely earmarked for science, should be increased to cover all the essentials of the "well-found laboratory". By thus expanding the scope of the equipment grant, UGC would have a firmer hold on the pattern of research as a whole, but would not be saddled with responsibility for making decisions between individual

\section{Deep-sea drilling}

\section{United Kingdom to miss out}

THE United Kingdom seems unlikely to participate in the Ocean Drilling Project (ODP), the new phase of deep-sea drilling scheduled to start at the beginning of next year. The situation has arisen from an unfortunate combination of an increase in cost compared with the previous drilling programme, a lack of financial support from the Department of Energy and the inability of the Natural Environment Research Council (NERC) to make good the shortfall of about $\$ 1$ million.

Since the beginning of the Deep Sea Drilling Project in 1968, the research ship Glomar Challenger has travelled 96 "legs", drilling more than 1,000 deep-sea cores. These have yielded information not only about the structure and evolution of sediments and ocean crust but also about climate, ocean chemistry and circulation in the past. At the start of the International Phase of Ocean Drilling (IPOD) in 1975, the annual cost of participation to member countries was $\$ 1$ million, when 70 per cent of the UK contribution was provided by NERC and the Advisory Board for the Research Councils (ABRC) and the remainder by the Department of Energy.

In the new phase of ocean drilling now being planned, several countries outside the United States have expressed an interest by the payment of $\$ 200,000$, permitting involvement in the planning stage. The United Kingdom has paid this sum, as have Canada and a consortium including Italy, Norway, Sweden and the Netherlands. France and Japan are also involved and are intending to become full partners, while the Federal Republic of Germany has already done so. By being a full partner, a country will be able to participate in the planning and on-board operation of individual legs and will have immediate access to the samples stored in core libraries in the United States.

The cost of full membership of ODP will be $\$ 2.5$ million a year, an increase of $\$ 0.5$ million over that of IPOD in its final year, The increased charge results principally from the cost of operating a new ship: the
A similar compromise is suggested by the Science and Engineering Research Council, which suggests that universities be invited to submit research plans which UGC would take into account in fixing grants. The council declares itself willing to follow that road, presumably confident that any such tightening of controls on the amount spent on research could work only in its favour. The Advisory Board for the Research Councils has recently published warnings of dire consequences for British science unless the level of financial provision is subsequently increased, and has now decided to embark on an international comparative study to gather ammunition for its case.

Tim Beardsley

Sedco/BP 471 owned 50:50 by Sedco Inc. of Dallas and BP. The new ship has more sophisticated drilling capability, better weather tolerance and twice the scientific crew capacity of Glomar Challenger.

In 1983, the Department of Energy was supporting deep-sea drilling to the tune of more than \$0.5 million. Although no final decision has been made concerning ODP, the signs are that the department is very unwilling to provide funds for the project. According to a spokesman, the department received considerable benefit from IPOD, but without a firm programme a question mark remains about the relevance of ODP to the department's needs.

Scientists involved with ODP express a mixture of anger and despair at this position. They emphasize that the first $21 / 2$ years of the project will see the exploration of the Labrador Sea and the Norwegian Sea - both areas closely related in geological terms to the Rockall region where the Department of Energy's interests have been mainly directed. They suggest that the department is being shortsighted, ignoring the strategic value of ODP's programme to the oil companies. Caustic remarks are made about the hole drilled in the Rockall area under the management of the department at a cost of $£ 25$ million, which, according to one scientist, revealed "virtually nothing of value". Supporters of ODP also emphasize the planned drilling in the Weddell Sea - an area of considerable British interest.

The task now is to persuade the government and the oil industry to make more money available. One strong supporter of ODP is Sir Peter Kent, one-time chairman of NERC and ex-chief geologist of BP, who points out the disparity between the cost of the project and the huge taxes paid by the oil companies on North Sea oil recovered with the help of ODP's predecessor. The oil companies are not slow to notice this disparity either, and are considering the situation through the UK Offshore Operators Association.

Philip Campbell 